\title{
EUTOMIA
}

Revista de Literatura e Linguística

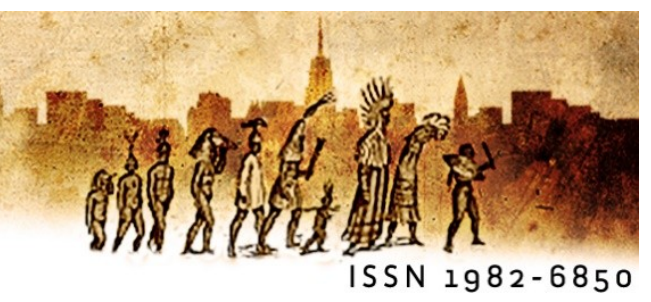

\section{Sound and decolonization: the enduring resonance of loss in Dulce Maria Cardoso's novel O Retorno}

\author{
Som e descolonização: a longa ressonância \\ da perda no romance $O$ Retorno de Dulce Maria Cardoso
}

\author{
Isabel A. Ferreira Gould ' (CEC, University of Lisbon)
}

\begin{abstract}
Through a close-reading of the 2011 novel $O$ Retorno, written by Portuguese novelist Dulce Maria Cardoso, my article examines literary representations of aural practices at the end of Portugal's African empire. The focus on listening and on the enduring resonance of loss reveals the complex and protracted process of decolonizing Portuguese identities.

Keywords: Dulce Maria Cardoso; listening; loss; decolonization; return.
\end{abstract}

Resumo: Através da leitura do romance $O$ Retorno, de 2011, da autoria da romancista portuguesa Dulce Maria Cardoso, o meu artigo examina representações literárias de práticas aurais no fim do império africano português. O enfoque na escuta e na longa ressonância da perda revela o processo complexo e prolongado de descolonizar identidades portuguesas. Palavras-chave: Dulce Maria Cardoso; escuta; perda; descolonização; retorno.

/E/m cada canto uma dor. Dulce Maria Cardoso, 2011, p. 32

Written by Portuguese novelist Dulce Maria Cardoso (b. 1964, Trás-os-Montes, Portugal), and published in 2011, O Retorno is a family novel and a narrative of loss. In her interview with journalist Carlos Vaz Marques, Dulce Maria Cardoso describes the concept behind her novel: "Pensei numa proposta de reflexão sobre a perda, sobre o que terá sido o colonialismo, nas suas raízes mais subterrâneas" (MARQUES, 2011). Tracing family separation and reunion in the context of Angola's decolonization and return to post- 
Revolutionary Portugal, the book focuses on the living experiences of imperial downfall, uprooting, and return migration among a family of former colonists. Through a closereading of the novel $O$ Retorno, my article examines literary representations of aural practices at the end of Portugal's African empire. The focus on listening and on the enduring resonance of loss reveals the complex and protracted process of decolonizing Portuguese identities. The novel shows us how sounds of decolonization, voices, murmurs, silences, and aural recollections of the colonial past still intrude into the Portuguese imagination and reverberate in the post-imperial present. O Retorno invites us to think critically about decolonization and to explore the long-term effects of imperial ruin. Despite the extensive body of studies on Portugal's African empire, practices of listening in the context of Portuguese colonialism and decolonization have only begun to receive attention (MOORMAN, 2019; GOULD, 2020).

\section{Decolonization and Return Migration}

Dulce Maria Cardoso's O Retorno offers a profound reflection on decolonization. For literary scholar Roberto Vecchi, the term decolonization says the unthinkable about a process that involved durability. Vecchi's central question, "qual é a duração, dentro desta consistência histórica, do suposto esvaziamento do colonialismo, do gesto fundador e formador de um modo português de fazer impérios?" (VECCHI, 2016, p. 44), emphasizes the need to study decolonization as a long and multifaceted process of emptying of colonialism. According to Vecchi, Portugal's last empire was shaped by the experience of an ending of time, whose genealogy can be traced back to the British Ultimatum (VECCHI, 2016, p. 46). As he further elaborates, "o próprio último império pode ser visto globalmente como o prolongado tempo do fim-uma qualidade mais do que uma duração que o carateriza, num estado de exceção permanente-que encontra uma contração no interstício revolucionário entre 25 de Abril e a descolonização" (VECCHI, 2016, p. 46). Roberto Vecchi invites us, on the one hand, to reflect on the plural meaning of the term decolonization to account for the proliferation of experiences, and, on the other hand, to auscultate colonial continuities in the post-imperial era (VECCHI, 2016, p. 48). Building on Vecchi's argument, I contend that the emblematic figure of decolonization, the returnee, embodies an image of rupture which does not fully represent colonial durability in the postcolonial era. 
The novel's title alludes to family resettlement and to return through memory. The idea of resettlement-of returning to the point of departure, to metropolitan Portugal, as the place that remained after the loss of the colonial home-suggests that the first generation of Portuguese returnees had already lost home when economic and social circumstances forced them to leave Portugal for colonial Angola. The term returnee [retornado] carried a stigma and pejorative connotation. It was coined in Portugal, in 1975, by the Instituto de Apoio ao Retorno de Nacionais (IARN), and it was used to refer to the 500,000 to 800,000 people who migrated from the former African colonies to postRevolutionary Portugal (PERALTA, 2017, p. 34-35). The term returnee applied specifically to white Portuguese decolonization migrants. It expressed the feelings of many metropolitan Portuguese citizens, who resented Portugal's imperial project, the colonial wars, and the return of ex-colonists. To the elite, the term referred to the remnants of empire, an idea that still resonates in contemporary discourse and literature. As literary scholar Raquel Ribeiro stresses, the image of the returnee is still today associated with "lixo' ou resíduo imperial" (RIBEIRO, 2015, p. 109). The notion of return, which the title encapsulates, also suggests the need to restore the past (LOWENTHAL, 1985, p. 40-41), here understood not only as the colonial past, but also as the past that preceded colonial experience. More than most, the times past did not lead to what was imagined for the future. As Dulce Maria Cardoso's novel shows, colonialism did not deliver on its promises.

One of the merits of $O$ Retorno is precisely to show that decolonization was not all rupture associated with the transition of power. In effect, the novel unsettles the story of progress that has been written to encapsulate the process of decolonization, suggesting that, despite the many dimensions of change, not only in politics and society, but also in individual experience and understanding, decolonization implied continuities across the colonial and the postcolonial periods. In my view, these continuities can be best understood through the study of soundscapes, aural memories, and post-imperial acoustics. Moreover, Dulce Maria Cardoso's book provides a narrative of decolonization "from below" by focusing on the lives of ordinary, non-elite white men and women during a period of political and social unrest. In Cardoso's striking narrative, sounds of upheaval, voices of discontentment, and silences matter.

The literary study of return and returnees invites us to discern the failures and shortcomings of Portugal's colonial project in Angola and the impact that decolonization 
had on ex-colonists and metropolitan citizens. The book conveys the idea that belonging, inclusion, and integration were shaped by construed perceptions of ethnic and racial difference. The novel suggests that Portuguese returnees adapted and integrated far more easily than African refugees, as they could "still trade on their whiteness," remarks historian Frederick Cooper (2003, p. 174). To many countrymen, returnees embodied the failures of Portugal's colonial project. In addition, returnees were viewed as being contaminated by the African experience. The disdain had its counterpart in the views of returnees. Many of the former colonists, who felt they had lived freer in the empire and farther from the core of the dictatorship, perceived metropolitan Portugal as being backward and lacking in cosmopolitanism, as Dulce Maria Cardoso's novel describes.

\section{Sounds of Upheaval and Imperial Downfall}

The novel $O$ Retorno opens with sounds of disruption and upheaval. Chaos and violence during Angola's transition to independence are explored from a Portuguese viewpoint. The family's last rituals in Angola are accounted through silence, mournful sounds, and noise against radio broadcasts of news of war casualties among Portuguese soldiers. Now sonically fractured, colonial Angola was built around images of unity, whiteness, and modernity enabled through radio sounds, as historian Marissa Moorman asserts (2019, p. 19-48). On the verge of becoming independent, the colony's remaining time unfolds in slow motion. Told from the subjective perspective of Rui, the youngest member of a family of four, the story describes the protagonist's adolescence while witnessing the end of colonialism and Portugal's status as an imperial nation. $O$ Retorno explores decolonization as an emptying of rituals that formerly comprised colonial life and identity. The first chapter, the longest of the book's 18 chapters, relates the distressing process of what Roberto Vecchi calls the emptying of colonialism (VECCHI, 2016, p. 44) in various episodes that lead to the father's detention, to family separation, and to the evacuation of the mother and the two children.

A particularly revealing episode in the novel is the family's final meal in Angola in what remains of the colonial home. The voice of the mother is filtered by her son Rui, the narrator. It is through him that we listen to all the sounds emitted, including the dog's cries. The uncanny sounds of the dog's whimpers express grief. "The animal lament accentuates 
the absence or the silence of what properly should be the sound of human mourning," as colonial and postcolonial studies theorist David Lloyd puts it in his examination of loss and mourning (LLOYD, 2003, p. 205). The dog's lament is a mournful sound that the people themselves are not able to voice about their impending dispossession and trauma. The father, the Portuguese colonist, does not have yet the language to describe the events surrounding the transition of political power. In an authoritarian demeanor, he pounds the table and rattles all the objects on it. The son's repetition of the words "antes de isto" (CARDOSO, 2011, p. 7)-invoking the discontinuation of the seemingly peaceful colonial past-expresses how their lives are changing beyond their comprehension. Like his father, Rui cannot express in words what will replace their colonial identity. Language-and, especially, the absence of language-is a central theme in O Retorno.

At crucial moments, time expands, and space constricts. To convey Rui's and his family's fears and anxieties, the novel depicts time as a prolonged ending and space as a losing ground during their last meal together. The changes in time and space convey that colonialism is already becoming unfamiliar. Time is represented in slow motion through the alternating use of sound and silence among the bewildered family members. Silence is interrupted by the mother's awkward interjections. She addresses her family artificially, sometimes as if she were talking to mere guests, sometimes as if she were talking to herself. Silence is also interrupted by the father's voice of anger. The background noise produced by the fan only partially insulates against the noise of gunfire from the street. The son looks to his father and partially expects him to be able to restore the time of the family in the space of the home. Nevertheless, sounds of events outside the house push the reluctant family to end their time in the colonial home. As the narrator tells,

A nossa última manhã. Tão silenciosa apesar dos tiros. Nem os tiros conseguem desfazer o silêncio da nossa partida, amanhã já não estamos aqui. Ainda que gostemos de nos enganar dizendo que voltamos em breve, sabemos que nunca mais estaremos aqui. Angola acabou. A nossa Angola acabou. (CARDOSO, 2011, p. 14)

As this passage shows, Rui's understanding of how he and his family hear silence and sounds of gunfire frames his conclusion that the time of colonial Angola is over.

The sound of gunfire is embedded in Dulce Maria Cardoso's book. Gunfire, cultural historian Diane Collins argues, announces a different political and social soundscape (COLLINS, 2017, p. 109). In O Retorno, the sound of gunfire punctuates feelings of distress 
over dispossession and alludes to the death of Portugal's colonial order. The focus on sound and listening to narrate decolonization and return emphasizes the role that acoustics play in accounts of trauma. Rui and his family heard gunfire as part of an acoustics of loss and expulsion. For the colonized seeking independence, gunfire introduces political change and consolidates the divide between colonialism and postcolonialism. The sound of gunfire communicates the victory of Angolan nationalism and introduces a new order. It is celebratory; it is an expression of political power against the imposed silence of Portuguese imperialism. For Angolans, the sound of gunfire embodies what Diane Collins calls an "acoustic of belonging" (2017, p. 111). Gunfire is a sound of independence. It is the most emblematic sound of belonging to a new era.

The novel's treatment of space contrasts with the notion of a prolonged end of time. The colonists are losing power and authority and the family home is all that is left of their colonial lives. Yet, the house offers only temporary refuge from the sounds of turmoil. The colonists' unclosed luggage suggests their delayed preparations and unwillingness to commit to leaving. The colonial home, the last remnant of colonialism, is not impermeable to the sounds of disruption the colonists can no longer control. The fleeing time of colonialism, which Rui's narrative delays, contrasts with the onrushing time of independence. The father's plan to burn down the house, and to kill the family's dog, so that the black population could not enjoy the colonists' way of living, a common and final act of imperial selfishness and exclusivity among colonists, announces the end of the colonial life. Yet this plan failed. It was foiled by Angolan independence forces, who detained the father at the door of the house.

In a series of flashbacks, Rui's narration takes the reader back to December 31, 1974, a few months before his father's arrest. On December 31, Sr. Manuel, a friend of the family, abandons Angola among the first wave of Portuguese colonists to seek refuge in Portugal. It is the same day the family prepares to attend the New Year's Eve dance with hundreds of other colonists who remained in Angola, hoping for a coup that would restore power to the white population and bring forth a new and independent African nation. The flashback voices turmoil, showing how the colonial community was polarized. Multiple divisions between the colonists who were leaving and those who were staying behind, between civilians and the retreating Portuguese military, between the colonists and the independence movements characterized the inhospitable environment. The figure of Sr. 
Manuel highlights the choice of the colonists who evacuated and returned to Portugal earlier, under safer conditions, able to protect their lives and assets; by contrast, Rui's family and many other colonists prolonged their stay and became increasingly vulnerable as independence approached. Sr. Manuel voiced many colonists' hatred for Portugal's Revolution and revolutionary heroes. In addition, he provocatively widened antagonisms among colonial Portuguese citizens. He disparaged the revolutionaries in the army and in Portugal as communists:

o Sr. Manuel odiava a revolução e os revolucionários, queria dizer mal da revolução tão alto e tão depressa que se engasgava, a cabeça em pêra do Sr. Manuel roxa de tanto tossir, o pai sorria, não diga disparates, homem, isto vai ficar melhor, vamos deixar de ser portugueses de segunda, [...] o Sr. Manuel recusava, você ri-se mas os comunistas da metrópole querem-nos fora daqui e vão conseguir, já desarmaram os nossos soldados, um branco não pode ter arma e um preto tem direito a duas, corja de traidores e vendidos, e não são só os comunistas, são todos, nem queiram saber o que dizem de nós na metrópole, o que nos chamam, lembrem-se do que hoje vos digo, vai haver aqui um mar de sangue. (CARDOSO, 2011, p. 28-29)

In other words, what most agitated Sr. Manuel was that Portugal itself was repudiating its own imperial project and abandoning its loyal agents. Sr. Manuel's words also function as a prophecy, a warning to the colonists who remained in Angola that they would perish. Contrasting with Sr. Manuel's confabulation on how the metropolitan central government had abandoned Portuguese colonists, Rui's father posed the question "como é que esta gente toda pode lá ir embora" (CARDOSO, 2011, p. 29) to immediately answer to himself "Aquela gente não pôde ter ido toda embora" (CARDOSO, 2011, p. 29). In stream of consciousness, this sequence of question and answer epitomizes the father's wavering between the old way of understanding colonial reality and the unrealistic plans for a newly white-ruled Angola.

\section{Sounds of White Luanda as 1974 Bled into 1975}

The 1974 New Year's Eve dance marks the end of colonialism, as colonists had lived it and imagined it. From then on, and until evacuation, ensues a short, but dreadful period of farewell. In a swirl of both disenchantment and euphoria, with the ball-room band playing off-key, hundreds of colonists drank heavily, sang in dissonance, and danced to the sound of Chico Buarque's 1966 song "A Banda." In the novel O Retorno, the song's opening words "o 
meu amor me chamou, pra ver a banda passar cantando coisas de amor, a minha gente sofrida, despedia-se ${ }^{1}$ da dor, pra ver a banda passar cantando coisas de amor" (CARDOSO, 2011, p. 29-30) quickly transition to the song's final words "mas para meu desencanto, o que era doce acabou, tudo tomou o seu lugar, depois que a banda passou, e cada qual no seu canto, em cada canto uma dor, depois de a banda passar, cantando coisa de amor" (CARDOSO, 2011, p. 31). In the context of Cardoso's novel, the lyrics suggest that after the band passes, despair returns. The New Year's Eve event was only a brief suspension in the agonizing time of the colonists. After the party, the life went back to its path of ruin.

Although ostensibly about love, the song in its original context was a coded protest against the dictatorship in Brazil in 1966. Yet, in Luanda, as 1974 bled into 1975, the colonists heard the song's desire for lasting love as a wish for their old regime to survive. The family's New Year's wishes that a dying colonialism could be reincarnated in a new form did not materialize.

\section{African-Portuguese Relations on the Eve of Angola's Independence}

Dulce Maria Cardoso's O Retorno explores African-Portuguese relations at the end of colonialism. In chapter one, we witness, through Rui's narration, the confrontation between black soldiers and the father in their front yard. The soldiers were in search of a wanted man, the butcher of Grafanil. It seems possible to us readers and to Rui that his own father was that man. The exchange delays the family's evacuation. This episode offers insights into the family's racism and colonialist views, including Rui's. The chapter denounces the father's and the son's ingrained racism, bigotry, and disdain for Africans (CARDOSO, 2011, p. 48-50). They not only voiced racist stereotypes, but also acted on the prejudice that infused Portugal's colonial project. The novel seems to suggest that Portuguese racism was hardening, not softening, as the African empire came to an end. It depicts the political transition leading to independence as a period of violence not only against the Portuguese, but also by Portuguese colonists.

In 1975, on the eve of Angola's independence, Portuguese civilians continued to voice their prejudice against the black population. In the view of Portuguese racists, black

\footnotetext{
${ }^{1}$ The word "despedia-se" does not conform with the original "despediu-se" in "A Banda."
} 
Angolans were unnamed, backward, and inferior (CARDOSO, 2011, p. 21, 25). In the view of black Angolans-according to the narrator-the colonist was "um esclavagista, um colonialista, um imperialista, um explorador, um violador, um carrasco, um gatuno, qualquer branco é isso tudo ao mesmo tempo e não pode deixar de ser odiado" (CARDOSO, 2011, p. 48). This passage is particularly revealing as it shows a rupture in Rui's narration to voice an African viewpoint. It is indeterminate if the passage refers to the narrator's construed imagination of what the soldiers were thinking or if it represents an insertion of the author's voice in the text.

The confrontation episode confirms the father's obstinate understanding of colonialism. Alternating between deceit, false benevolence, paternalism, and condescendence, the father's words matched his own actions:

\begin{abstract}
olhem bem para mim, fala alto como para uma multidão, digam-me o que vêem, eu digo-vos o que estão a ver, estão a ver um homem que se matou a trabalhar nesta terra, descarreguei sacas de café contigo, contigo, aponta para cada um dos soldados, com o teu pai, com o teu tio, com o teu irmão, com o teu filho, não há homem que tenha descarregado mais sacas de café nesta terra do que eu, trabalhei dia e noite e agora, o pai pára de falar e quando recomeça fá-lo com a voz mais baixa, como se lhe custasse falar, tudo o que tenho vai ficar aqui, olhem para as minhas mãos, não cabem mais calos nas minhas mãos [...], o pai estende as mãos enormes para os soldados, tanto trabalho para agora ficar tudo aqui, o pai aponta para a casa, [...], os soldados continuam calados, o pai parece estar a ganhar, lembremse da minha cara de cada vez que se sentarem à minha mesa, [...] o pai levanta mais a voz, a cara do homem a quem tudo foi roubado não deve ser esquecida, lembrem-se bem. (CARDOSO, 2011, p. 56)
\end{abstract}

In this passage, the father speaks through the narration of his son in free indirect speech. Rui's mediation of his father's voice allows Rui to merge the two voices. The shared perspective between father and son underscores Rui's complicity in his father's imperial worldview. What we read is what Rui filters and reports. The father asserts that because he worked alongside black laborers, the fruits of their joint labor belong solely to him. This was the father's way of masking his exploitation of African labor. What prevails in their colonialist assessment is the self-image of a hard-working immigrant in fraternal relations with Africans. This passage shows how the novel depicts the family's elision of the two key principles of Portuguese colonialism: the appropriation of land and the exploitation of labor. In Rui's account, his father is a victim. The son interprets the soldiers' silence as submission to the father's argument. Yet what emerged was the soldiers' confrontation, not any 
submission. The soldiers challenged the father's authority by ceasing to recognize his colonial status. They addressed him informally, mimicked his speech, and laughed. We hear both the distressed laughter of Rui's father and the defiant laughter of the soldiers. The sound of laughter plays a central role in the novel.

The confrontation in Rui's house ended in the worst possible way: the father was wounded and taken by the soldiers. From a certain moment on, we have access only to Rui's auditory testimony and aural memories. His temporary loss of vision during the encounter is suggestive of the traumatic nature of the event, but not of his own colonial contrition. There was no guilt here. Rui voiced only fear of revenge and retribution for Portuguese acts of violence against Africans. Rui and his adolescent friends had also been involved in racialized violence and abuse. They had beaten a black boy (CARDOSO, 2011, p. 49-50) and had subjected a black woman to gang sex (CARDOSO, 2011, p. 43). He feared that the soldiers had come to capture him. There is just a brief hint of guilt; it came to Rui's mind that his father was being sought for what he and his friends had done.

In Dulce Maria Cardoso's novel, Portuguese characters, including the narrator, view and hear Africans and Afro-descendants with contempt both in Angola and in postRevolutionary Portugal (CARDOSO, 2011, p. 79, 85, 92). As historian Miguel Bandeira Jerónimo argues, "o racismo foi certamente uma gramática organizadora e legitimadora de uma 'ordem imperial' moderna" (JERÓNIMO, 2016, p. 216). Agreeing with Jerónimo's assertion, I contend that Portuguese racism has branched into other grammars that have legitimized the political orders of decolonization and postcolonialism. These newer grammars do not dispense with prejudice, as the ongoing work of journalist Joana Gorjão Henriques (HENRIQUES, 2016) shows Us. If race impacts perception, "sound and listening enable racism's evolving persistence," as American studies and sound studies scholar Jennifer Lynn Stoever asserts (2016, p.5).

\section{The (In)Audible (Re)Turn}

In contrast with the extended treatment of the brief confrontation between the colonists and the soldiers, the family's escape to Portugal is covered in a few pages. The treatment of noise at the airport, both internal noise- "este barulho que não pára, parece que a minha cabeça vai explodir" (CARDOSO, 2011, p. 59)-and external noise— "o barulho 
das pessoas, o barulho dos motores dos aviões lá fora, os gritos da criança" (CARDOSO, 2011, p. 62)-, conveys the chaos of decolonization and its impact on the narrating self. Rui's narration shows how language filters and pieces together the experience of trauma. Rui's fragmented and traumatic memories are meticulously placed in the last sentence of each paragraph describing family separation and turmoil at the airport. There are eighteen sentences that show the return of Rui's traumatic memories. Through these memories of trauma, Rui's mind and the reader's attention return to his home and to the scene of the confrontation. At the airport, while preparing to embark, his memory becomes more and more complete as he recalls more about losing his father and home. At the airport, aural and visual memories of trauma combine and emerge.

The novel adopts the viewpoint of the adolescent who loses a parent. Rui's narrative expresses the voice of suffering and mourning of the fatherless child. In his narrative of relocation to Portugal, Rui assumes the role and place of his father, the patriarch of the family. Rui believes his father is dead. Rui's narration centers on his new obligations to care for his mother and sister in Portugal, in the hotel where they and hundreds of other former colonists are given temporary refuge. Rui is a fatherless figure who gives voice to his double loss of father and empire. Rui tells the reader key aspects of his father's fate in Angola that he and his family conceal from the people with whom they interact. Rui's narration unveils fragments of the untold story of his father's captivity. This is seemingly a self-imposed silence. The topic is not to be discussed outside the family and even within it. Yet, this is not just a family idiosyncrasy, but a national pattern. Post-Revolutionary, celebratory Portugal left no room to entertain narratives of retaliation against ex-colonists in Angola, in 1975. If the empire were still in existence, the suffering of the child who lost a parent to African resistance would be legitimate. After empire, however, there is no legitimacy to Rui's suffering.

\section{Loss and Remains}

Rui's experience of loss of home shapes his narrative of decolonization. Rui's question "como é que se faz para voltar para casa" (CARDOSO, 2011, p. 81) condenses the narrator's displacement and mourning for the loss of home. Dulce Maria Cardoso's unmitigated reflection on loss invites the reader to entertain a question posed by literary 
scholars David Eng and David Kazanjian: What remains after loss? Eng and Kazanjian explain that "loss is inseparable from what remains, for what is lost is known only by what remains of it, by how these remains are produced, read, and sustained" (ENG \& KAZANJIAN, 2003, p. 2). In other words, loss is incomplete. It includes a memory of what is no longer available. Loss and mourning are inseparable themes that convey the agony of the absence of empire and the pains of entering post-coloniality. For the returnees, making a home in post-imperial Portugal meant "habitar em dor," according to literary scholar Helena Carvalhão Buescu (2008, p. 298).

The process of decolonization found resistance in post-imperial Portugal. In the hotel, where Rui, his mother and sister, and many other ex-colonists received temporary refuge until they could rebuild their lives and homes, the returnees attempted to occupy the present and themselves with stories of the past. In contrast to the idea of decolonization as emptying, the stories we hear through Rui's individual testimony fill the void, resisting the fragmentation and dilution of colonial memories. One of the virtues of Dulce Maria Cardoso's book is that it decants stories and memories that resist decolonization and remain after the loss of the last empire.

Among the various characters described in the novel, Pacaça is the one we hear most through the narrator's testimony. Pacaça, whose nickname alludes to an African buffalo subspecies and to a tree native to Mozambique, is a spokesperson for returnee women, children and men at the IARN-provided hotel. He was born in Angola, lived in Mozambique and was a hunter. He described itself as a double returnee from Angola and Mozambique. He earned his nickname for the 469 pacaças killed at first and the 257 with attempts, though his goal was to reach one thousand pacaças. Pacaça is an excellent storyteller. The post-imperial present is filled with his stories and memories of hunting wild boars, fawns, leopards, lions, and crocodiles. He was a collector of trophies and embalmed heads. He is the character who never stops talking, claiming rights, denouncing problems, talking about politics and politicians, telling adventures of game hunting.

It is Pacaça who organizes guards at night on the piers of Lisbon, where the returned goods from the empire were stored temporarily. Rui is part of the men's guard on the piers. When not making rounds, the men sit by the fire reliving hunting adventures in the African empire. As Rui narrates, 
Calhou-me fazer a primeira ronda aos contentores com o Faria. Já tínhamos acendido a fogueira e o Pacaça tinha posto a água ao lume para fazer café. As fogueiras lembram-me as caçadas, pensando bem isto também é uma caçada, se apanhar alguém com as patas nos contentores atiro a doer, já me roubaram o que tinham a roubar, palavra de honra e de Pacaça. (CARDOSO, 2011, p. 192)

In this passage, we find that Rui fuses the memory of bonfires with the memory of hunting, creating by association a new memory in the present. The fire on the piers of Lisbon now calls to mind a hunting expedition. We see how Rui's and Pacaça's words intertwine in the reconstruction of memories. The nostalgic stories of the two returnee men become hybrid, infiltrating the present, echoing the colonial past. The stories of colonial game hunting that we hear in post-imperial Lisbon represent a form of evasion against the present. In the aftermath of decolonization, storytelling of animal hunting brings the characters closer to the past.

\section{Conclusion}

My article explores the literary treatment of decolonization and return migration by focusing on listening, soundscapes, and post-imperial acoustics. It establishes interconnections between loss and listening. The article argues that to apprehend what it meant to be a colonist during the twilight of empire and a returnee in post-imperial Portugal, we must study how sounds were heard and how the colonial past continues to resonate in the present. Studying acts of listening and aural practices in literature centered on colonialism and its demise creates new paths of understanding political transitions and societal changes. Moreover, my article shows how we can read literature-and fiction, in particular-as both an aural practice and a space for/of listening, as literary scholar Marilia Librandi proposes in her book Writing by Ear (LIBRANDI, 2018, p. 8, 45). In my view, literature not only allows for a critical listening to the past, but also expounds the enduring resonance of empire, inviting us to listen to what anthropologist Ann Laura Stoler designates as "imperial durabilities" in the present (STOLER, 2016). If colonialism silenced the colonized, decolonization initiated a new acoustic regime. Narrated from the perspective of the uprooted, Dulce Maria Cardoso's 2011 novel O Retorno offers the reader an acoustics of dispossession at the end of empire, while Angola celebrates its new, resounding beginnings. 


\section{Cited references}

ALMEIDA, Paula Cardoso, org. Descolonização. O Drama da Integração. Volume 8. Vila do Conde: Verso da História, 2015.

BUESCU, Helena Carvalhão. Emendar a Morte. Pactos em Literatura. Porto: Campo das Letras, 2008.

CARDOSO, Dulce Maria. O Retorno. Lisboa: Edições tinta-da-china, 2011.

CARDOSO, Dulce Maria. The Return. Translated from the Portuguese by Ángel GurríaQuintana. London: Maclehose Press, 2016.

COLLINS, Diane. "Starling Reports. Gunfire as Social Soundscape in Early Colonial Australia." In DAMOUSI, Joy, Paula Hamilton, ed. A Cultural History of Sound, Memory and the Senses. NY: Routledge, 2017. 107-122.

COOPER, Frederick. "Postcolonial Peoples: A Commentary." In SMITH, Andrea L., ed. Europe's Invisible Migrants. Amsterdam: Amsterdam University Press, 2003. 169-183.

DAMOUSI, Joy, Paula Hamilton, ed. A Cultural History of Sound, Memory and the Senses. NY: Routledge, 2017.

ENG, David L. and David Kazanjian, ed. Loss. The Politics of Mourning. Los Angeles: University of California Press, 2003.

GOULD, Isabel A. Ferreira. "Acoustic Remains: Listening for Colonialism and Decolonization in Isabela Figueiredo's Life-Writing." In PERALTA, Elsa, org. Narratives of Loss, War, and Trauma: Portuguese Cultural Memory and the End of Empire. Forthcoming, 2020. 22 pages.

HENRIQUES, Joana Gorjão. Racismo em Português: O Lado Esquecido do Colonialismo. Lisboa: Edições tinta-da-china, 2016.

JERÓNIMO, Miguel Bandeira. "Posfácio: As gramáticas da diferença que o racism nomeou." In HENRIQUES, Joana Gorjão. Racismo em Português: O Lado Esquecido do Colonialismo. Lisboa: Edições tinta-da-china, 2016. 215-224.

LIBRANDI, Marilia. Writing by Ear: Clarice Lispector and the Aural Novel. Toronto: University of Toronto Press, 2018.

LLOYD, David. "The Memory of Hunger." In ENG, David L., David Kazanjian, ed. Loss. The Politics of Mourning. Berkeley: University of California Press, 2003. 205-228.

LOWENTHAL, David. The Past is a Foreign Country. Cambridge: Cambridge University Press, 1985. 
MARQUES, Carlos Vaz. "O Retorno de Dulce Maria Cardoso." LER 29.09.2011.

MOORMAN, Marissa. Powerful Frequencies: Radio, State Power, and the Cold War in Angola, 1931-2002. Athens, Ohio: Ohio University Press, 2019.

PERALTA, Elsa. "Introdução: Retornar, ou Traços de Memória num tempo presente." In Peralta, Elsa, Bruno Góis, Joana Oliveira, coord. Retornar. Traços da Memória do Fim do Império. Lisboa: Edições 70, 2017. 31-42.

PERALTA, Elsa, Bruno Góis, Joana Oliveira, coord. Retornar. Traços da Memória do Fim do Império. Lisboa: Edições 70, 2017.

RIBEIRO, Raquel. "O Retorno, uma Cartografia Emocional Ainda por Escrever." In ALMEIDA, Paula Cardoso, org. Descolonização. O Drama da Integração. Volume 8. Vila do Conde: Verso da História, 2015. 106-127.

SMITH, Andrea L., ed. Europe's Invisible Migrants. Amsterdam: Amsterdam University Press, 2003.

STOEVER, Jennifer Lynn. The Sonic Color Line. Race \& The Cultural Politics of Listening. NY: New York University Press, 2016.

STOLER, Ann Laura. Duress. Imperial Durabilities in Our Times. Durham: Duke University Press, 2016.

VECCHI, Roberto. "Os fins do tempo do fim: descolonização, negação, pertença." Saggi/Ensayos/Essais/Essays 16 (November 2016): 43-51.

\footnotetext{
' Isabel A. Ferreira Gould holds a Ph.D. in Portuguese and Brazilian Studies from Brown University. She is an independent scholar and a collaborating researcher at the University of Lisbon's Centre for Comparative Studies. She has published articles in scholarly journals and edited volumes on topics such as family, intergenerational memory, genealogical consciousness, war, colonialism, postcolonialism, dictatorship, torture, trauma, travel, and the natural environment in literature. Her current research focuses on listening, ear-witnessing, and aural memories in contemporary literature that revisits colonialism and the transition from dictatorship to democracy in Portugal and on hunting narratives written under and after Portuguese colonial rule in the African continent. She taught at Brown University, Harvard University, University of Notre Dame, University of Massachusetts-Dartmouth, Rhode Island College, and the University of Rhode Island.

E-mail: isabelferreiragould@gmail.com
} 